OPEN ACCESS

Vol. 9, No. 1, April, 2021

Page. $1-10$

DOI: https://doi.org/10.21107/jaffa.v9i1.9941
JOURNAL OF AUDITING, FINANCE, AND FORENSIC ACCOUNTING

E-ISSN: 2461-0607 ISSN: 2339-2886

https://journal.trunojoyo.ac.id/jaffa

\title{
The Effect of The Existence of Internal Audit Function and Internal Audit Disclosure
}

Putri Retno Asri, Erfan Muhammad*

Accounting Departement, Faculty of Economics and Business, Universitas Trunojoyo Madura

\section{Article Info:}

Received: February 15, 2021

in revised form: March 1, 2021

Accepted: 22 April 2021

Available Online: 30 April 2021

\section{Keywords:}

Audit fee service, existence of Internal Audit Function (IAF), Internal Audit Disclosure (DIA)

\section{Corresponding Author:}

Email:

erfan.muhammad@trunojoyo.ac.id
Abstract; This study aims to examine and analyze the effect of the existence of an internal audit function (IAF) and internal audit disclosure (DIA) on external audit fees in non-financial companies listed on the Indonesia Stock Exchange in 2015-2019. The approach used in this study is a quantitative study consisting of 327 samples with purposive sampling technique. Data analysis in this study using multiple linear regression. The results showed that the existence of the internal audit function (IAF) had a negative and insignificant effect on the audit fee service, while the disclosure of the Internal Audit (DIA) had a significant positive effect on the fee service audit. Control variables, namely company size, return on assets, public accounting firms and subsidiaries are used to avoid it bias element.

Abstrak; Penelitian ini bertujuan untuk menguji dan menganalisis pengaruh keberadaan internal audit function (IAF) dan pengungkapan internal audit (DIA) terhadap external audit fee pada perusahaan nonkeuangan yang terdaftar di Bursa Efek Indonesia tahun 2015-2019. Metode penelitian yang digunakan dalam penelitian ini adalah penelitian kuantitatif yang terdiri dari 327 sampel dengan teknik purposive sampling. Analisis data dalam penelitian ini menggunakan regresi linier berganda. Hasil penelitian menunjukkan bahwa keberadaan internal audit function (IAF) berpengaruh negatif tidak signifikan terhadap audit fee service sedangkan pengungkapan Internal Audit (DIA) berpengaruh positif secara signifikan terhadap audit fee service. Variabel kontrol yaitu ukuran perusahaan, return on asset, kantor akuntan publik dan anak perusahaan digunakan agar terhindar dari unsur bias. 


\section{INTRODUCTION}

Based on the phenomenon of giving audit fees that continues to increase annually in a company and the widespread need for professional services of public accountants as independent parties, the public accounting profession is required to improve its performance so that the resulting audit products can be relied on by those in need. Indonesia is an interesting research setting because Indonesia already has a standard that regulates the official amount of audit fees, namely the Management Regulation concerning the Determination of Fees for Financial Statement Audit Services in 2016 (Institut Akuntan Publik Indonesia(IAPI), 2016). In addition, there is an obligation to disclose the audit fee in the Financial Services Authority Circular Letter No.30 / SEOJK.04 / 2016.

Regarding the fee service audit, in 2016, there were allegations of providing fictitious financial reports to PT Timah (Persero) Tbk in the first semester of 2015 (Nurdiana, 2020). Further study regarding the issue of providing high audit fees has an impact on the quality of the audit process, namely in June 2019 the non-financial company on the IDX, namely PT. Garuda Indonesia (Persero) Tbk, namely the negligence of KAP Tanubrata, Sutanto, Fahmi, Bambang and Partners in the 2018 financial year audit (Putri, Andrea dan Arkananta, Putu, 2020). Non-financial companies in Indonesia have the largest emissions, namely 570 compared to other types of companies listed on the IDX, then Humairo, Aisyah et al., (2018) from 2013 to 2017 the results of the analysis on the audit fee trend chart of Real Estate and Property Companies tend to be followed a straight line (increased) except in 2015 so that the object used by researchers was non-financial companies on the IDX that were recorded in the 2015 to 2019 period.

This study is a replication of the research of Sourour Hazami-Ammar (2019) which confirms that internal audit working hours have a positive effect on external auditor costs while IAF quality has a negative effect on external audit costs in Tunisia (North Africa). In preventing an element of bias towards the results of the study, the researchers referred to Dopuch's first study in 1980. N., and Simunic, D. Regarding factors that have an impact on the scale of fees received by auditors, control variables are used, namely company size, return on assets, public accounting firms, and subsidiaries which refer to Rizqiasih's research (2010).

The difference between this study and the research of Sourour Hazami-Ammar (2019) is that the independent variables used are more complex, namely the existence of an internal audit function (IAF) and disclosure of Internal Audit (DIA), while previous research in Tunisia used the quality of the internal audit function (IAF) and working hours. internal audit. Then the external audit fees used by researchers include audit fee services which are measured using the value of public accountants' fees in the financial statements or annual reports, whereas in previous studies focused on external auditor fees as measured by the logarithm of professional fees. Then the object of research is non-financial companies, while the previous research used a database of responses from French internal auditors from the Institute of Internal Auditors proprietary Global Auditing Information Network (GAIN).

Thus, the researcher wanted to prove whether the existence of the internal audit function (IAF) and internal audit disclosure (DIA) in non-financial companies had an effect on the audit fee service so that the researcher formulated the title, "The Effect of the Existence of the Internal Audit Function (IAF) and Internal Audit Disclosure DIA) on External Audit Fees"

\section{LITERATURE REVIEW AND HYPOTHESES DEVELOPMENT}

\section{The Effect of the Existence of the Internal Audit Function (IAF) on External Audit Fees}

Singh and Newby (2009) in research (Aryani and Rosinta, 2010) argue that the relationship between the internal audit function and the external audit fee includes two views, namely: 


\section{Substitution}

The view that emphasizes the existence of a negative relationship to all existing control mechanisms and control systems that are added as a deduction to other control functions, or one and the other is replaced.

\section{Complementary (Complementary Control View)}

The view that emphasizes the completeness and strength of other control functions is the impact of the added control system and the complementary functions of the external auditor with internal audit.

International Standard Attribute Standards (Institut Auditor Internal (IIA), 2008) stating the competence, objectivity, nature and scope of activities as well as the relative investment in the internal audit function (IAF) are the scope of the quality of IAF actions. The IAF attribute includes the first three groups above because it shows the characteristics of the organization that performs internal audit activities. Research by Sourour Hazami-Ammar (2019) found a negative relationship with the quality of the internal audit function (IAF), which has an effect on lower external audit costs. Based on the substitution view, the use of internal auditors' performance can reduce the time and efforts of external auditors, so that the resulting auditor costs are reduced (Axen, 2018). According to IARF (2013) in Axen, Linus (2018) emphasizes that the central role of IA is to evaluate and improve the effectiveness of risk management, control, and governance procedures. As an effort to reduce work on external auditors, IAF has the ability to reduce and control the risks inherent in the company. Wallace (1984) in Axen, Linus (2018) exemplifies the contribution of internal auditors in reducing audit fees to be low by increasing corporate accounting controls and providing assurance services related to management risk and control processes so that there is a significant negative relationship between the existence of the IAF and the costs of external auditors.

The agency theory in Ramdani (2016) states that a third party, namely an independent auditor, functions in solving agency problems from managers to owners or shareholders through the audit process. External auditors will experience problems when faced with all interests with the quality of the internal audit function (IAF) on internal control, increasing the dependence of external auditors on client internal control, so that the costs of external auditors decrease because the risk of auditing has decreased. Based on the theoretical analysis and the results of the above research, it raises empirical questions about the relationship between the existence of the internal audit function (IAF) and the external auditor fee, namely the audit fee service, the researchers suspect and formulate the following hypothesis:

H1: The existence of an internal audit function (IAF) in non-financial companies has a negative effect on the audit fee service

\section{The Effect of Internal Audit Disclosure (DIA) on External Audit Fees}

Based on Law No.40 (2007) as well as Bapepam LK XK6 (2012) regulations state financial accounting standards, namely companies that are listed must prepare and submit and submit annual financial reports after the financial year is completed (no later than 4 months) to submit reports the Financial Services Authority (OJK) and requires companies to make disclosures to public services which materially affect the share price in a period of two days, including disclosure of internal audit (DIA) in PSAK No. 7 regarding related party disclosures. Internal audit is an audit of internal activities with an independent and objective nature designed to add and improve in organizational operations and achieve goals and objectives effectively efficiently and to improve the quality of risk management and management of operational activities (Board of Directors IIA, 2009). Beekes, W., and Brown, P, (2006) in Axen, Linus (2018) found evidence that other companies using more informative disclosures in annual reports differentiate themselves from companies with superior governance quality.

Internal audit disclosure describes how the company's internal audit works and functions or carries out activities for the company, namely the higher its performance or authority and its existence, the more disclosures that are produced. In a complementary view, if the company issues high disclosure costs, it shows a high internal audit function and must be followed by external audit as a complement to carry out the audit process maximally or in detail, the company will pay high costs so that the resulting report is better. Then Sourour Hazami-Ammar (2019) emphasized that an increase in 
internal audit working hours has a significant positive effect on external audit costs. Strengthened by research, Sawan (2016) confirms the results of his research, namely the amount of audit fees has a positive effect on internal audit compliance with performance standards and attribute standards. If the internal auditors comply with these standards, the external audit fee will also increase. As well as research Laura Sierra, Garcia., Et. al., (2018) which states that the internal audit function has a positive effect on the costs of external auditors.

Agency theory explains that the high abnormal audit fee can cause auditors to be more tolerant of opportunistic management activities such as negotiations regarding giving company opinions when there is a deficit (Ramdani, 2016). According to IARF (2013) in Axen, Linus (2018) the central role of internal audit is to evaluate and increase the effectiveness of control management and governance processes. Then Lalu Axen, Linus (2018) emphasized that if companies that disclose more informative internal audits have high internal audit quality, it will have a positive effect on audit fees. The hope of the high quality of internal audit is that more internal reviews and reports will be generated because the exchange for other governance mechanisms will increase, including the company board and the audit committee. The more reports and reviews that an increase in the external auditor's performance burden may occur so that the external auditor's fee also increases (Zain, M., Zaman, M., dan Zulkifflee, M., 2015). Based on the theoretical analysis and the results of the above research, it raises empirical questions about the relationship between internal audit disclosure (DIA) and external auditor fees, namely audit fee service, the researchers suspect and formulate the following hypothesis:

H2: Internal audit disclosure (DIA) on non-financial companies has a significant positive effect on fee service audits

\section{RESEARCH METHODOLOGY}

\section{Research Overview}

The quantitative research approach is used in this study. The population chosen by the researcher was all non-financial companies on the Indonesia Stock Exchange that were listed from 2015 to 2019 by taking samples through the purposive sampling method. There are 570 non-financial companies registered as of December 31, 2019, after processing the sample using purposive sampling technique on non-financial companies listed on the IDX, totaling 570 companies. However, based on the results of the sample selection, there are only 65 non-financial companies that can be used as research samples. Thus, the number of samples that can be processed and used in this study is 327 samples of non-financial companies in the 2015 to 2019 financial reporting period. The data analysis technique used is descriptive statistics, classical assumption test, multiple linear regression analysis, partial test ( $t$ test) and determination coefficient test which were processed using SPSS 23 software.

\section{Research Model}

The reseacrh model used, can be seen in figure 1 as follows:

\section{Types and samples of research}

This research is a descriptive quantitative study. The type of data used is secondary data. Population of this research were Index Kompas 100 company on Indonesia Stock Exchange (IDX), period 2016-2018. The sampling used is nonprobability sampling techniques, with the category of purposive judgment sampling. The method used in analyzing data is multiple linear regression, using the SPSS software version 21 .

\section{Research Model}

The research model used, can be seen in figure 1 as follows: 


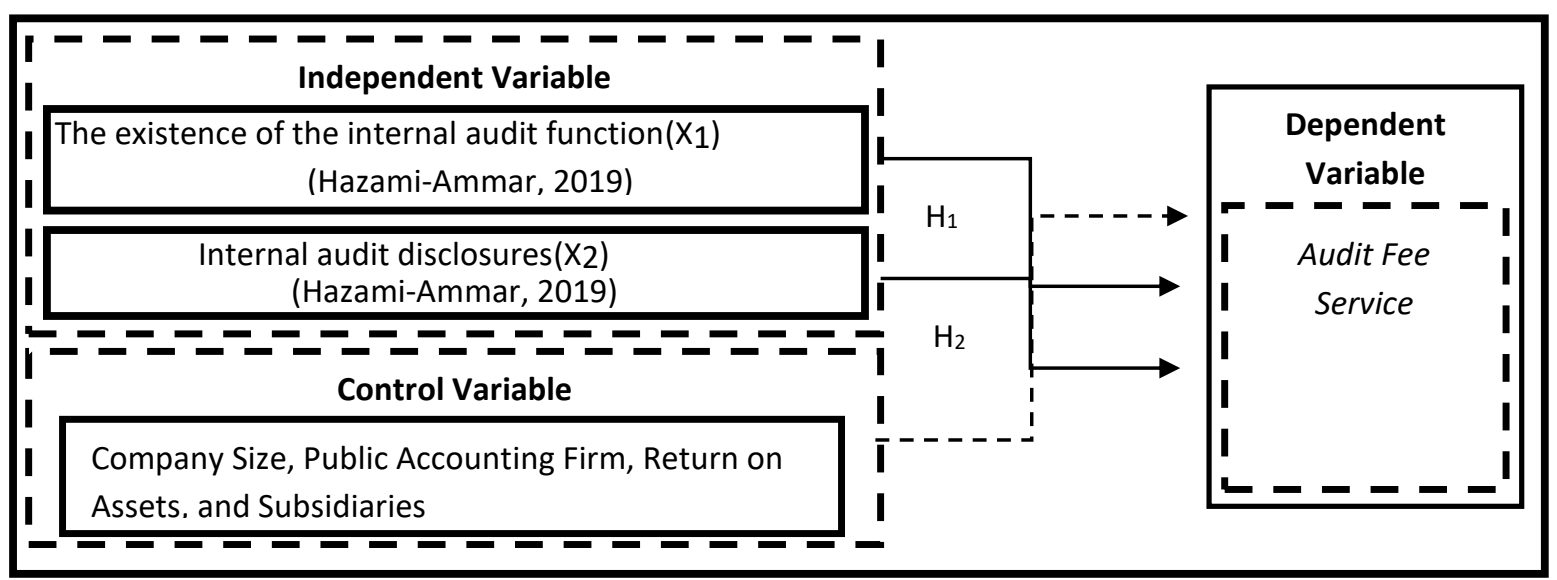

Figure 1

Research Model

\section{Operational Variable}

The explanation operational variable, can be seen in table 1 , as follows:

Table 1

Operasional Variabel

\begin{tabular}{|c|c|c|}
\hline No. & Recearch Variables & Measurement \\
\hline 1. & $\begin{array}{l}\text { Audit fee service } \\
\text { (LNFEEAS) based on } \\
\text { research conducted by } \\
\text { (SPAP (IAPI, 2008)). }\end{array}$ & $\begin{array}{l}\text { Audit fee service is the dependent variable obtained } \\
\text { from the public accountant's audit fee value in the } \\
\text { financial statements. }\end{array}$ \\
\hline 2. & $\begin{array}{l}\text { The existence of an } \\
\text { internal audit function } \\
\text { (IAFACT) based on } \\
\text { research conducted by } \\
\text { (Hazami-Ammar, 2019). }\end{array}$ & $\begin{array}{l}\text { The use of an internal audit function (IAF) is measured } \\
\text { as a dummy variable, with code } 1 \text { indicating that the } \\
\text { company has an internal audit function (IAF). }\end{array}$ \\
\hline 3. & $\begin{array}{l}\text { Internal audit disclosure } \\
\text { (DIA) based on research } \\
\text { conducted by (Hazami- } \\
\text { Ammar, 2019). }\end{array}$ & $\begin{array}{l}\text { Internal audit disclosure (DIA) is measured by giving } \\
\text { code } 1 \text { if the company discloses a minimum of } 5 \\
\text { specific information related to IA including IA's } \\
\text { structure and unit, IA charter, internal audit profile (IA } \\
\text { personnel), IA's duties and authorities, legal basis, IA } \\
\text { qualification or certification., IA education or training, } \\
\text { a brief description of IA's implementation or activities } \\
\text { in the year of the annual report, as well as the internal } \\
\text { control system, if less than } 5 \text { specifications are given } \\
\text { code } 0 \text {. }\end{array}$ \\
\hline 4. & $\begin{array}{l}\text { Company size } \\
\text { (LNASSETS) based on } \\
\text { research conducted by } \\
\text { (Rizqiasih, 2010) }\end{array}$ & $\begin{array}{l}\text { The natural logarithm of the company's total assets at } \\
\text { the end of the year is a tool for measuring the firm size } \\
\text { variable. }\end{array}$ \\
\hline 5. & $\begin{array}{l}\text { Public accounting firm } \\
\text { (BIG4) based }\end{array}$ & $\begin{array}{l}\text { KAP variables were measured using dummy variables. } \\
\text { Value } 1 \text { is for companies that use KAP BIG } 4 \text { services } \\
\text { and value } 0 \text { otherwise. }\end{array}$ \\
\hline 6. & $\begin{array}{l}\text { Subsidiary (SUBSDR) } \\
\text { based on research } \\
\text { conducted by } \\
\text { (Rizqiasih, 2010) }\end{array}$ & $\begin{array}{l}\text { The total of the subsidiary's square root is a measure of } \\
\text { this variable. }\end{array}$ \\
\hline 7. & $\begin{array}{l}\text { Return on Assets (ROA) } \\
\text { based on research } \\
\text { conducted by Halim } \\
(2005)\end{array}$ & $\begin{array}{l}\text { ROA : } \\
\text { Total income after tax }\end{array}$ \\
\hline
\end{tabular}

Source: Processed Data 


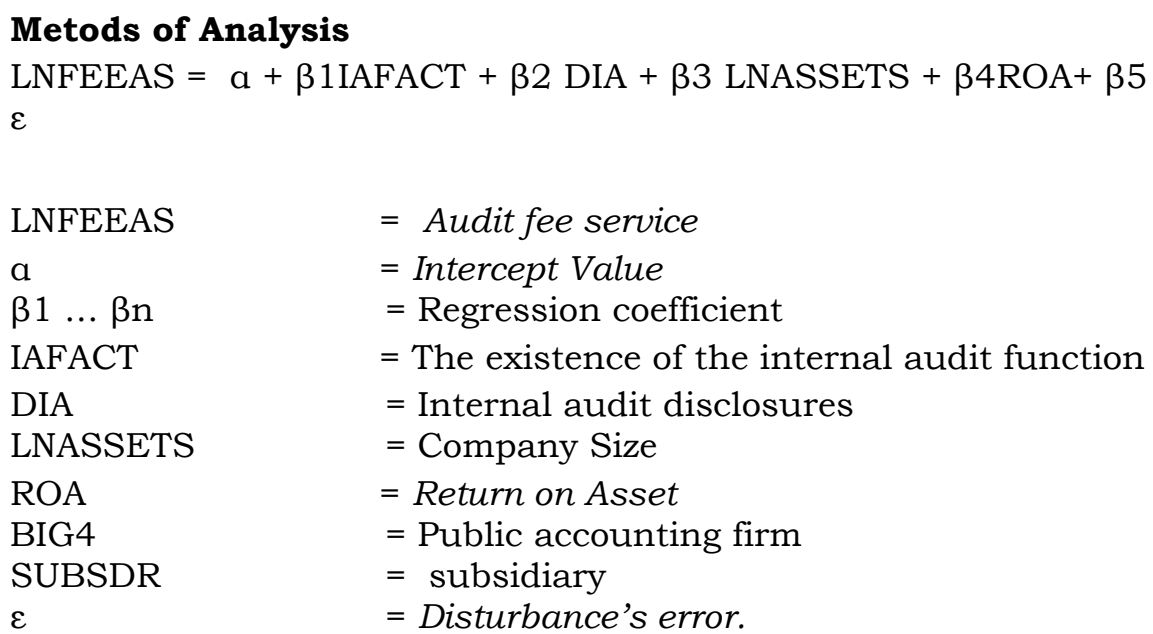

\section{FINDINGS AND DISCUSSION}

\section{Descriptive Statistical Analysis}

Based on descriptive statistics, the audit fee service is obtained from the value of the public accountant's audit fee on the financial report or annual report. The average audit fee service in the study was $20.51 \%$ and a standard deviation of $1.29 \%$. The mean value of the firm size in the study was $28.64 \%$ and the standard deviation was $1.59 \%$.

The mean value of return on assets in this study is $0.05 \%$ with a standard deviation of $0.17 \%$. The minimum value of return on assets in this study is $-1.46 \%$ at PT Leyand International Tbk, then the largest value is $0.74 \%$ at PT Akasha Wira International Tbk. The mean value of the subsidiaries in the sample companies is $2.03 \%$ and the standard deviation is $1.46 \%$. The largest value of the variable in the study was $8.09 \%$ at PT Siloam International Hospitals Tbk, while the minimum value was $0 \%$ at PT Akasha Wira International Tbk.

Table 2

Descriptive statistics

\begin{tabular}{ccc}
\hline & Frequency & Percent \\
\hline Passive & 5 & 1.5 \\
\hline Active & 322 & 98.5 \\
\hline Total & 327 & 100.0 \\
\hline
\end{tabular}

Source: SPSS 23 Output Results, 2020

From table 2, the existence of the internal audit function (IAF) in the audit fee service variable, the frequency is 327 with the details of the inactive sample, namely 5 samples to a percentage of $1.5 \%$. Meanwhile, the frequency of the existence of the internal audit function (IAF) on the audit fee service variable is 322 to the percentage of $98.5 \%$.

On the basis of table 3 , the internal audit disclosure (DIA) in the audit fee service variable has a frequency of 327 , with the details of the sample being inactive in the study, namely 47 and the percentage of $14.4 \%$. Meanwhile, the frequency of internal audit disclosure (DIA) on the audit fee service variable is 280 and the percentage is $85.6 \%$.

Table 3

Descriptive statistics

\begin{tabular}{crr}
\hline & Frequency & \multicolumn{1}{c}{ Percent } \\
\hline Passive & 47 & 14.4 \\
\hline Active & 280 & 85.6 \\
\hline Total & 327 & 100.0 \\
\hline
\end{tabular}

Source: SPSS 23 Output Results, 2020 
Table 4

Descriptive statistics

\begin{tabular}{ccr}
\hline & Frequency & Percent \\
\hline Non BIG4 & 211 & 64.5 \\
\hline BIG4 & 116 & 35.5 \\
\hline Total & 327 & 100.0 \\
\hline
\end{tabular}

Source: SPSS 23 Output Results, 2020

From table 4, the use of KAP BIG 4 has a frequency of 327 with a breakdown of the sample that does not use KAP BIG 4, namely 211 and the percentage is $64.5 \%$. Then the frequency of use of KAP BIG 4 in the sample is 116 , the percentage is $35.5 \%$.

\section{Classic Assumption Test Results}

The results of the classical assumption test show that the data in this study have met the requirements of the classical assumption test. The test results prove that the data is normally distributed without symptoms of multicollinearity, heteroscedasticity, and autocorrelation.

Table 5

Multiple Linear Regression Test Results

\begin{tabular}{llll}
\hline & \multicolumn{3}{c}{ LNFEEAS } \\
\hline Variabel & \multicolumn{3}{c}{ MODEL REGRESI } \\
\cline { 2 - 4 } Independen & \multicolumn{1}{c}{ Koefisien } & \multicolumn{1}{c}{ T } & Sig \\
\hline (constant) & 8.464 & 8.287 & $.000^{*}$ \\
\hline IAFACT & -.205 & -.563 & .574 \\
\hline DIA & .261 & 2.057 & $.040^{*}$ \\
\hline LNASSETS & .394 & 11.444 & $.000^{*}$ \\
\hline ROA & 1.116 & 4.246 & $.000^{*}$ \\
\hline BIG4 & .670 & 6.789 & $.000^{*}$ \\
\hline SUBSDSR & .216 & 6.270 & $.000^{*}$ \\
\hline R square & .656 & & \\
\hline F statistic & 101.879 & \\
\hline F Sig & $.000 \mathrm{~b}$ & \\
\hline Source: SPSS 23 Output Results, 2020
\end{tabular}

Information:

${ }^{*}=$ statistically significant at the $5 \%$ level of significance.

\section{Partial Test Results ( $t$ Test)}

On the basis of table 4 above, the results of the partial test in the study are:

\section{The Effect of the Existence of Internal Audit Function (IAF) on External Audit Fees}

Based on table 5, the t-test value for the existence of the internal audit function variable at LNFEEAS is -0.563 at a significant level of 0.574 so that it is greater than 0.05 with the conclusion that the presence of an internal audit function has a negative and insignificant effect on the audit fee service. The hypothesis (H1) is accepted because the hypothesis is proven. Based on the research of Sourour Hazami-Ammar (2019), it found a negative relationship with the quality of the internal audit function (IAF), which has an effect on lower external audit costs.

Thus, the agency theory in Ramdani (2016) emphasizes that the third party, namely the independent auditor, functions to resolve agency problems from managers to owners or shareholders through the audit process. External auditors will experience problems when faced with all interests with the quality of the internal audit function (IAF) on internal control, increasing the dependence of external auditors on client internal control, so that the costs of external auditors decrease because the risk of auditing has decreased.

Based on the theory used as well as research by Sourour Hazami-Ammar (2019), the results of this study state that the Internal Audit Function (IAF) serves as a supervisor or is authorized as internal control over external auditors so that the risk of auditing will be reduced or low because internal control increases so that reports the financial results are accurate and not risky, thus the audit fees received by the auditors 
will also be low.

\section{The Effect of Internal Audit Disclosure (Dia) on External Audit Fees}

Table 5 shows the $t$ test value of the internal audit disclosure variable on LNFEEAS, which is 2.057 at a significant level of 0.040 , so it is smaller than 0.05 with the conclusion that the number of internal audit disclosures (DIA) has a significant positive effect on fee service audits. The hypothesis (H2) is accepted because the hypothesis is proven.

The results of this study are supported by research by Sourour Hazami-Ammar (2019) which confirms that increased internal audit working hours have a significant positive effect on external audit costs. As well as research Laura Sierra, Garcia., Et. al., (2018) emphasized that the internal audit function has a positive effect on the costs of the external auditor.

Agency theory explains that high abnormal audit fees can cause auditors to be more tolerant of opportunistic management activities such as negotiations regarding giving company opinions when there is a deficit (Ramdani, 2016). According to IIARF (2013) in Axen, Linus (2018), the central role of internal audit is to evaluate and increase the effectiveness of control management and governance processes.

Based on research from Hazami-Ammar (2019), Sawan (2016), Zain and Zulkifflee (2015), and Laura Sierra, Garcia., Et. al., (2018) and the suitability of the theory used, get the results that internal audit is a complement to the external auditor fee, so the performance of external auditors, such as internal audit, works. Thus, the internal audit performance becomes neat and thorough, and the costs obtained by the audit are higher than the external audit, thus spurring the external audit to work better to produce better quality.

\section{The Effect of Company Size on External Audit Fees}

Table 5 presents the t-test value of the firm size variable (LNASSETS) on LNFEEAS of 11,444 at a significant level of 0.000 , so it is smaller than 0.05 with the conclusion that company size has a positive and significant effect on the audit fee service The hypothesis (H2) is accepted because the hypothesis is proven. This study proves that as a control variable, company size is measured by the natural logarithm of total assets. There is a positive and significant effect on external auditor fees. The larger the company size in the financial statements, the greater the fee received.

The results of this study are reinforced by research by Rewczuk, Karol and Modzelewski, Piotr (2019), Pradana, Satria EN, and Purwanto, Agus (2016), Sanusi, Muhammad A. and Purwanto, Agus (2017), Yulianti, Nova., Agustin, Henri., And Taqwa, Salma (2019) discussing the effect of company size on external auditors. This relationship can be related to the condition of the company, whose total assets are relatively stable, and the ability to generate profits will increase.

\section{The Effect of Return On Asset on External Audit Fees}

The t-test value of the return on assets (ROA) variable on LNFEEAS is 4,246 at a significant level of 0,000 and less than 0.05 , so the conclusion is that return on assets has a positive and significant effect on the audit fee service, so the hypothesis (H2) is accepted.

Contrary to the research of RIZ (2005) which emphasizes the high Return on Assets (ROA) in the company has an impact on the low fees charged and remains consistent with the client risk sharing auditor.

\section{The Effect of Public Accounting Firms on External Audit Fees}

The t-test value of the Public Accounting Firm (BIG4) on LNFEEAS is 6,789 at a significant level of 0,000 , less than 0.05 , with the conclusion that KAP (BIG4) has a significant positive effect on the fee service audit, so the hypothesis (H2) is accepted.

The high quality of KAP or public accountants results in minimal errors compared to auditors whose quality is low so that they have different fee payments from the two (Rizqiasih, 2010). This research strengthens the research of Sanusi, Muhammad A., and Purwanto, Agus (2017), Tat, Robertus NE, Murdiawati, Dewi (2020), and Yulianti, Nova., Agustin, Henri., And Taqwa, Salma (2019) with KAP BIG4 has a significant positive effect on fee service audits. 


\section{The Influence of Subsidiaries on External Audit Fees}

The value of the subsidiary variable $t$ test (SUBSDSR) on LNFEEAS is 6,270 at a significant level of 0.000 , so it is smaller than 0.05 . The conclusion is that the subsidiary has a significant positive effect on the fee service audit with the hypothesis (H2) accepted. The total of the subsidiary companies is measured by the square measure. This variable is used as a control variable with proxies having a positive effect on the audit fee service.

This research is reinforced by Rizqiasih, (2010) that the representative of subsidiaries for providing audit service complexity is a complex measure of whether or not transactions belonging to KAP clients are to be audited. Beams stated in (Halim, 2005) as well as in (Rizqiasih, 2010), if the company has a domestic subsidiary, the client has more complex transactions because it requires making consolidated reports. Meanwhile, if the company has a subsidiary overseas, the transactions belonging to the client will be more complex because it requires the preparation of a reasurement report or the preparation of a transaction report and afterwards a consolidated report is prepared.

\section{CONCLUSION AND SUGGESTIONS}

From the results of statistical analysis, it shows that the disclosure of audit fee services is still relatively small with 570 non-financial companies, only 65 non-financial companies can be used as research samples. This means that not many non-financial companies have complied with the disclosure of fees for quarterly audits and reviews, in the regulations, namely SEC Final Rule S7-13-00: Revision of the Commission's Auditor Independence Requirements and Financial Services Authority Circular Letter No.30/ SEOJK.04/2016.

From the results of multiple linear regression analysis with a tool, namely SPSS 23, the conclusions are obtained, namely: the existence of the Internal Audit Function (IAF) has a negative and insignificant effect on the audit fee service in non-financial companies on the IDX registered for the period 2015 to 2019. The view of internal substitution audit function with an external audit fee is rejected or not proven in this study. Disclosure of Internal Audit (DIA) has a significant positive effect on fee service audits in non-financial companies listed on the IDX for the period 2015 to 2019. A complementary view of the internal audit function on external audit is proven in this study, namely if the company incurs high disclosure costs, it shows high internal audit function and must be followed by external audit as a complement to carry out the audit process maximally or in detail, the company will incur high costs so that the resulting report is better. Company size, return on assets, public accounting firms and subsidiaries have a significant positive effect on the audit fee service for non-financial companies listed in the IDX for the period 2015 to 2019. The two independent variables in this study have never been used directly in Indonesia. these controls have helped to avoid an element of bias in the results of studies that refer to Dopuch's first 1980 study. N., and Simunic, D. related to factors that have an impact on the scale of fees received by auditors.

From these conclusions, it is suggested that further researchers need to do different measurement proxies such as professional fees and different sectors such as financial companies in Indonesia to obtain sufficient data and better results. For companies to avoid fraud in the audit process, comply with the Financial Services Authority Regulation Number 55/POJK.04/2015 regarding the existence of an internal audit function (IAF) in companies so that the audit results on financial reports from external auditors are accurate and not risky, thus audit fees demand for auditors will also be low. Then for external auditors to avoid fraud in obtaining high audit service fees, look for companies that disclose high internal audits because the fees earned will also be high based on this research.

\section{REFERENCES}

Aryani, D., \& Rosinta, F. (2010). Pengaruh kualitas layanan terhadap kepuasan pelanggan dalam membentuk loyalitas pelanggan. Jurnal Bisnis Dan Birokrasi, Ilmu Administrasi Dan Organisasi, 17(2), 114-126. 
Auditors, T. I. of I. S. and G. (2018). International standards for the professional practice of internal auditing (STANDARDS. Almont Springs, FL 32701-4201, USA, (October), 1-22.

Axén, L. (2018). Exploring the association between the content of internal audit disclosures and external audit fees: Evidence from Sweden. International Journal of Auditing, 22(2), 285-297. https://doi.org/10.1111/ijau.12120

Board of Directors IIA. (2009). Pengertian Internal Audit.

Halim, A. (2005). Analisis Investasi. Jakarta: Salemba Empat.

Hazami-Ammar, S. (2019). Some evidence on the impact of internal audit on external audit fees. Journal of Corporate Accounting \& Finance, 30(2), 64-81. https://doi.org/10.1002/jcaf.22384

Herdiana. (2013). Pengaruh Fee Audit, Audit Tenure, Rotasi Audit Dan Ukuran Perusahaan Klien Terhadap Kualitas. Journal of Chemical Information and Modeling, 53(9), 1689-1699.

Humairo, A., Rahayu, S., \& Rahayu. (2017). Analisis Jumlah Fee Audit pada Perusahaan Real Estate dan Properti yang Terdaftar di Bursa Efek Indonesia Periode 2013-2017. Universitas Jambi, (3), 1-12.

Institut Auditor Internal (IIA). (2008). International Professional Practice Framework. The Institute of Internal Auditor Inc

Mulyadi. (2002). Auditing I (6 ed.). Jakarta: PT Salemba Empat.

Nasution. (2003). Metode Penelitian Naturalistik Kualitatif. Bandung: Tarsito.

Nurdiana, E. R. (2017). Auditor Terhadap Kualitas Audit Pada Kap Jakarta Timur \& Selatan. Jurnal Akuntansi Sekolah Tinggi Imu Ekonomi Indonesia, (5), 1-21.

Peraturan Otoritas Jasa Keuangan Nomor 55/POJK.04/2015. (2020, Maret 18). Tentang Pembentukan dan Pedoman Pelaksanaan Kerja Komite Audit. Diambil kembali dari www.ojk.go.id:www.ojk.go.id/regulasi/peraturanojk/POJKNomor55.POJK.03.2015/.

Rizqiasih, P. D. (2010). Pengaruh Struktur Governance Terhadap Fee Audit Eksternal. Universitas Diponegoro.

Sawan, A. A. N. (2016). Journal of Financial Reporting and Accounting Article information: Journal of Financial Reporting and Accounting, 14(1), 1-20.

Sierra-García, L., Ruiz-Barbadillo, E., \& Orta-Pérez, M. (2019). Analysis of the influence of the internal audit function on audit fees. Revista de Contabilidad-Spanish Accounting Review, 22(1), 100-111. https://doi.org/10.6018/rc-sar.22.1.354351

Toscano M., J. A., \& Garcia-Benau, M. A. (2014). Structure and Nature of Competition in the Market for Financial Audit Services in Mexico. Journal of Business Administration Research, 3(2), 1-10. https://doi.org/10.5430/jbar.v3n2p1

Zain, M. M., Zaman, M., \& Mohamed, Z. (2015). The Effect of Internal Audit Function Quality and Internal Audit Contribution to External Audit on Audit Fees. International Journal of Auditing, 19(3), 134-147. https://doi.org/10.1111/ijau.12043 